\title{
The Effect of Baby Massage on Improvement Baby Weight
}

\author{
Nurul Fatmawati ${ }^{1}$, Yesvi \\ Zulfiana $^{2}$, Yopi Suryatim \\ Pratiwi $^{3}$ \\ ${ }^{1}$ Bachelor of Midwifery, \\ Stikes Yarsi Mataram \\ ${ }^{2}$ Bachelor of Midwifery, \\ Stikes Yarsi Mataram \\ ${ }^{3}$ Bachelor of Midwifery, \\ Stikes Yarsi Mataram \\ Email: \\ nurulf_10@yahoo.com
}

Received: March 14 2021

Accepted : April 16 2021

Published : May 20 2021

\begin{abstract}
The problem experienced by toddlers is that growth disorders in Indonesia have started to emerge from children aged 1-6 months, so that efforts are needed to reduce the rate of growth disorders or to or to increase weight presentation. Increasing body weight is an indicator of infant health that can be used as a benchmark for infant growth. Body weight is the most important anthropometric measure and is most often used in newborns (neonates). One of the treatments that can be done to increase body weight is by giving massage to babies. Baby massage can stimulate the penvernaan hormones insulin and gaselin, so that food absorption becomes better. This causes babies to feel hungry quickly so they eat more often and gain weight. The purpose of this study was to determine the effect of infant massage on infant weight gain. The method in this study is a literature review, which tries to explore how the effect of infant massage on infant weight gain. The results in this study indicate that the results of 6 previous studies indicate that there is a significant effect of infant massage on the increase in infant body weight. The conclusion in this study is that massage in infants can increase the baby's weight. This is because the massage that is carried out regularly on babies is used to massage the legs, stomach, chest, hands, back, and stretching movements can increase the baby's weight. The massage will cause nerve action potential that stimulates the vagus nerve.
\end{abstract}

Keywords: Baby massage, eight gain, infant

Copyright (C) 2021 IIK STRADA Indonesia All right reserved.

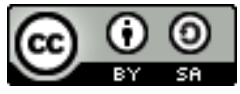

This is an open-acces article distributed under the terms of the Creative Commons Attribution-ShareAlike 4.0 International License.

\section{INTRODUCTION}

Countries around the world in 2010 in order to accelerate human development and poverty eradication have a joint commitment known as Millenium Development Goals (MDGs), and is expected to be achieved in 2015. Program objectives MDGs in Indonesia, one of which is the reduction of child mortality, namely by creating a national program to reduce the number of infant and under-five mortality including low birth weight (LBW). 
The human development index is determined by the level of public health. Based on data from the 2017 Indonesian Health Demographic Survey (SDKI, 2017), the Infant Mortality Rate (IMR) in Indonesia is still high, namely 24 deaths per 1,000 live births. The high IMR in Indonesia is mostly related to nutritional factors at $53 \%$. Some of the diseases that arise due to malnutrition include pneumonia (20\%) and diarrhea (15\%) (Ministry of Health RI, 2013).

Growth includes increased weight, height, head and arm size, teeth, and several other body changes. While growth in children includes motor, sensory, cognitive and psychosocial. (Susanto, A. 2014) The problem experienced by toddlers is that growth disorders in Indonesia have started to emerge from children aged 1-6 months, so that efforts are needed to reduce the rate of growth disorders or to or to increase weight presentation. (Jahari, et al. 2000) Increasing body weight is an indicator of infant health that can be used as a measure of infant growth. Body weight is the most important anthropometric measure and is most often used in newborns (neonates). Birth weight is used to diagnose normal or low birth weight (LBW) babies. It is called low birth weight (LBW) if the baby is born under 2500 grams or under $2.5 \mathrm{~kg}$. In infancy / toddlerhood, body weight can be used to see the rate of physical growth and nutritional status (Nursalam, et al. 2013).

One of the recommended stimuli is baby massage. Baby massage, also known as tactile stimulation, is the art of health care and medicine that has been practiced for centuries. Baby massage, among other things, can stimulate the penvernaan hormones insulin and gaselin, so that food absorption becomes better. This causes babies to feel hungry quickly so they eat more often and gain weight. (Vivian, 2010) The increase in children's body weight in the first year of life when the child gets better nutrition from birth to 6 months of weight gain per week of 140-200 grams. Babies weigh twice their birth weight at the end of the first 6 months. Meanwhile, at the age of 6-12 months, body weight increases per week ranging from 85-400 grams. Body weight will increase 3 times body weight at the end of the first year of birth (Hidayat, 2008)

Some studies suggest that baby massage can stimulate the vagus nerve, which increases intestinal peristalsis, which regulates the function of organs including the chest and abdomen. Stimulation of the vagus nerve (parasympathetic nerve) will stimulate the stomach to release the hormone gastrin. On the other hand, massage also improves blood circulation and increases cell metabolism, from which the baby's weight will increase. This is supported by studies showing the results that premature babies who were massaged three times fifteen minutes for ten days, gained 20$47 \%$ more weight than babies who were not massaged. (Field, at all, 1986)

Based on this background, the authors are interested in making a literature review entitled "The Effect of Infant Massage on Baby Weight Gain"

\section{MATERIALS AND METHODS}

Researchers chose literature review as the research method in this paper, which tries to explore how the effect of infant massage on infant weight gain. Sources for conducting this literature review include systematic computerized database search studies (Pubmed, Pro Quest, and google scholar). Literature review is a research methodology that aims to collect and take the essence of previous research and analyze some of the expert's overview written in the text. (Snyder, 2019) 
The Effect of Baby Massage on Improvement Baby Weight.....

\section{RESULTS}

Several studies have shown that there is an effect of infant massage on infant weight gain. This can be seen in the following table:

Table 1. Judgment Results from the Literature Review

\begin{tabular}{|c|c|c|c|c|}
\hline Year & Author & Reseach purposes & Method & The Result \\
\hline 2020 & $\begin{array}{l}\text { Susi Hartati, } \\
\text { Desmariyenti, } \\
\text { Nurul } \\
\text { Hidayah }\end{array}$ & $\begin{array}{l}\text { The purpose of this } \\
\text { study was to } \\
\text { determine the effect } \\
\text { of infant massage on } \\
\text { infant weight gain }\end{array}$ & $\begin{array}{l}\text { The method in this } \\
\text { research is quasi } \\
\text { experimental with } \\
\text { cross sectional } \\
\text { research design }\end{array}$ & $\begin{array}{l}\text { The results showed that the } \\
\text { p-value }<0.05 \text {. This means } \\
\text { that } 0.000<0.05 \text { means that } \\
\text { there is an effect of infant } \\
\text { massage on increasing the } \\
\text { baby's body weight }\end{array}$ \\
\hline 2019 & $\begin{array}{l}\text { Vitrianingsih, } \\
\text { Sonia Dora } \\
\text { Cardoso, Sitti } \\
\text { Khadijah }\end{array}$ & $\begin{array}{l}\text { The purpose of this } \\
\text { research is to } \\
\text { determine the effect } \\
\text { of infant massage on } \\
\text { baby weight. }\end{array}$ & $\begin{array}{l}\text { The method in this } \\
\text { research is quasi- } \\
\text { experimental. }\end{array}$ & $\begin{array}{l}\text { The results showed that there } \\
\text { was an effect of infant } \\
\text { massage on baby weight gain } \\
\text { (p-value } 0.007<0.05 \text { ) }\end{array}$ \\
\hline 2019 & $\begin{array}{l}\text { Sharifa } \\
\text { Mohammed } \\
\text { Ali Al } \\
\text { Balushi, } \\
\text { Victoria } \\
\text { Funmilayo } \\
\text { Hanson }\end{array}$ & $\begin{array}{l}\text { The purpose of this } \\
\text { study was to assess } \\
\text { the effect of infant } \\
\text { massage on baby } \\
\text { weight gain. }\end{array}$ & $\begin{array}{l}\text { The method in this } \\
\text { research is quasi- } \\
\text { experimental }\end{array}$ & $\begin{array}{l}\text { The results in this study } \\
\text { indicate that infant massage } \\
\text { shows a positive effect. }\end{array}$ \\
\hline 2017 & Ida Susila & $\begin{array}{l}\text { The purpose of this } \\
\text { research is to find the } \\
\text { effect of baby } \\
\text { massage techniques } \\
\text { on weight gain. }\end{array}$ & $\begin{array}{l}\text { The method in this } \\
\text { study used a pre- } \\
\text { experimental } \\
\text { design (One Group } \\
\text { Pretest Design). }\end{array}$ & $\begin{array}{l}\text { The results showed that there } \\
\text { was a significant effect of } \\
\text { infant massage } \\
\text { on infant weight gain with a } \\
\text { significance of } 0.000 \text {. With } \\
\text { the results of } t \text { table } \\
\text { equal to } 0.0 \text { and p of } 0.000 \text {. } \\
\text { This shows a p value }<0.05 \\
\text { and a } \mathrm{z} \text { value of }-3.793 \text { then } \\
\mathrm{H} 1 \text { is accepted. }\end{array}$ \\
\hline 2015 & $\begin{array}{l}\text { Zahra } \\
\text { Akbarian } \\
\text { Rad, Mohsen } \\
\text { Haghshenas, } \\
\text { Yahya } \\
\text { Javadian, } \\
\text { Mahmoud } \\
\text { Hajiahmadi, } \\
\text { Fahimeh } \\
\text { Kazemian }\end{array}$ & $\begin{array}{l}\text { The purpose of this } \\
\text { study was to assess } \\
\text { the effect of infant } \\
\text { massage on weight } \\
\text { gain. }\end{array}$ & $\begin{array}{l}\text { The method in this } \\
\text { study was a non- } \\
\text { randomized } \\
\text { blocking clinical } \\
\text { trial }\end{array}$ & $\begin{array}{l}\text { The results in this study were } \\
\text { the mean infant weight } \\
\text { between the two groups did } \\
\text { not have a statistically } \\
\text { significant difference on day } \\
4 \text {, however this difference } \\
\text { became significant after day } \\
4 \text { with a p-value of } 0.007 \text {. }\end{array}$ \\
\hline 2014 & Umi Kalsum & The purpose of this & The design used & The results of this study \\
\hline
\end{tabular}


The Effect of Baby Massage on Improvement Baby Weight.....

\begin{tabular}{llll}
\hline Year Author & \multicolumn{1}{c}{ Reseach purposes } & \multicolumn{1}{c}{ Method } & \multicolumn{1}{c}{ The Result } \\
\hline study was to & $\begin{array}{l}\text { was quasi- } \\
\text { determine the effect } \\
\text { of massage on } \\
\text { increasing infant } \\
\text { weight }\end{array}$ & $\begin{array}{l}\text { indicated that there was an } \\
\text { analyzed by } \\
\text { statistical testing } \\
\text { the Mann Whitney }\end{array}$ & $\begin{array}{l}\text { increasing body weight, } \\
\text { namely } \mathrm{p}=0.033 ; \alpha=0.05 .\end{array}$ \\
& test & $\begin{array}{l}\text { From the results of the paired } \\
\text { sample t-test in the control } \\
\text { group, the value of } \mathrm{p}= \\
\end{array}$ & \\
& & $0.0517 ; \alpha=0.05$.
\end{tabular}

\section{DISCUSSION}

Baby massage is a therapy or health care art that has long been known by humans and is a treatment that has been practiced since the beginning of humans being created in the world, because the process is related to human pregnancy and birth. Humans experience the first experience of being massaged at birth in the world with the birth process where they have to leave the warm uterus and pass through a narrow birth canal, causing traumatic experiences and anxiety. Touch and massage the baby that is done immediately after birth will make the baby maintain a sense of security after being guaranteed contack with the baby's body (Roesli, 2013).

Baby massage is also called touch therapy which means it is a technique that combines the physical benefits of human touch with emotional benefits such as bonding. Infant massage is also an alternative effort to achieve the simplest degree of health that can be done at home, in addition, baby massage can also lead to an inner contact between children and parents (Pratyahara, 2012). Massage is a form of touch therapy that serves as an important treatment technique (Kalbe, H. 2001).

Massage in infants can increase the baby's weight. This is because babies who are massaged have increased levels of absorption enzymes and insulin so that absorption of food juices is better. As a result, babies become hungry quickly and therefore breastfeed more frequently, thereby increasing milk production. Massage also increases the mechanism of absorption of food by the vagus nerve so that the baby's appetite will also increase which can directly increase the baby's weight (Syaukani, 2015).

The activity of the Nervus Vagus is influenced by the absorption of food, that in infants who are massaged, the tone of the nervus vagus (10 th brain nerve) will increase which will cause an increase in levels of the enzyme absorption of gastrin and insulin. Thus, the absorption of food will be better with the massage than the one not massaged. (Field, at all. 1986)

The results showed that babies who were massaged regularly from birth often gained weight faster than others, perhaps because massage stimulated the production of growth hormones.

Other benefits of baby massage are that it can develop communication, reduce stress or pressure and reduce pain disorders or reduce pain. The mother can increase milk production, understand baby's cues, increase self-confidence and understand the baby's needs. In addition, the benefits of baby massage in general are that it can increase endurance, improve blood circulation and respiration, stimulate digestive and excretory functions, increase weight gain, reduce stress and tension, increase alertness, make sleep more soundly, reduce pain (such as flatulence and abdominal pain), improves the inner connection between parent and baby, and increases the production of breast milk. (Subakti, 2008) 


\section{CONCLUSION}

Based on the research results, it can be concluded that massage in infants can increase the baby's weight. This is because the massage that is carried out regularly on babies is used to massage the legs, stomach, chest, hands, back, and stretching movements can increase the baby's weight. The massage will result in the potential for nerve action that stimulates the vagus and then stimulates an increase in intestinal peristalsis, so that food absorption in the body will be maximized. Massage in babies can also improve blood circulation and increase cell metabolism, so that the baby's weight will increase. Based on the results of the study, it was also concluded that there was an effect of massage on babies on weight gain.

\section{ACKNOWLEDGMENTS}

Thanks to Stikes Yarsi Mataram and friends of the Undergraduate Program Midwifery Study Program who have provided a lot of input and suggestions for the implementation of this research.

\section{CONFLICTS OF INTEREST}

In this study the authors have an interest in seeing how the effect of infant massage techniques on infant weight gain.

\section{REFERENCES}

Zahra Akbarian Rad, Mohsen Haghshenas, Yahya Javadian, Mahmoud Hajiahmadi, Fahimeh Kazemian. (2015). The Effect of Massage on Weight Gain in Very Low Birth Weight Neonates. Journal of Clinical Neonatology |Published by Wolters Kluwer. 10.4103/2249-4847.179900 DOI

Field TM, \& Schanber SM. (1986). Tactile/Kinesthetic Stimulation Effect On Preterm Neonatus

Hidayat. (2008). Nursing Research and Scientific Writing Techniques. Edition 2. Jakarta: Publisher Salemba Medika.

Ministry of Health RI. Indonesia's Helth Profile. (2013). Jakarta: Ministry of Health of The Republic of Indonesia

Kalbe, Farma. (2001). A Good Way to Take Care of Your Little One Jakarta: PT. Sanghiang Perkasa

Department of health. Maternal and Child Health Books. Jakarta: Ministry of Health RI

Susanto Ahmad. (2014). Early Childhood Development. Jakarta: Kencana

Nursalam et all. (2013). Infant and Child Nursing Care For Nurses and Midwives. Jakarta: Salemba Medika

Susi Hartati, Desmariyenti, Nurul Hidayah. (2020). Effects of Baby Massage on Weight Gain in Babies. Journal Of Midwifery And Nursing Vol 2, No. 2

Roesli, U. (2013). Guidelines for Infant Massage. Jakarta: Library of Archipelago Self-Help Development

Vivian, Nanny, L. D. (2010). Upbringing of Neonatus Infants and Toddlers. Jakarta: Salemba Medika Publishe

Jahari AB, Sanjadja, Sudiman H, Soekirman, at all (2000). Nutritional Status of Toddlers in Indonesia Before and After the Crisis

Snyder, H. (2019). Literature review as a research methodology: An overview and guidelines'. Journal of Business Research, 104, pp. 333-339

Subakti. (2008). The magic of Baby Massage. Jakarta: Wahyu Media

Sharifa Mohammed Ali Al Balushi, Victoria Funmilayo Hanson. (2017). Efect Of Neonatal Massage On Weight Gain And Physical Responses Among Preterm Babies In Selected Hospital In 
Fujairah, United Arab Emirate. International Journal of Nursing, Midwife and Health Related Cases Vol.5, No.3, pp.20-33

Pratyahara. (2012). The magic of Touch Therapy for Your Baby Yogyakarta:Javalitera

Vitrianingsih, Sonia Dora Cardoso, Sitti Khadijah. (2019). The Effect Of Baby Massage On Baby's Weighr In Pratama Kususma Medisca In wates Yogyakarta. International Respati Health Conference Yogyakarta

Syaukani Aulia, (2015) Practical Instructions for Healthy Massage, Gymnastics, and Yoga for Babies for Maximum Growth and Development.Yogyakarta, Araska.

Ida Susila. (2017). Effect of Infant Massage Techniques on Weight Gain for Infants aged 0-7 Months at BPS. Aida Hartatik. Midpro Journal, Vol. 9 No. 2 